\title{
Performance indicators of work activity
}

\author{
Manoela de Assis Lahoz and João Alberto Camarotto \\ Universidade Federal de São Carlos (UFSCar) - Industrial Engineering Department - Simucad Ergo\&Ação \\ Group (www.simucad.dep.ufscar.br) Rodovia Washington Luiz, km 235 - São Carlos, SP, Brazil - 13.565-905. \\ manoela@dep.ufscar.br; camarotto@dep.ufscar.br
}

\begin{abstract}
The measurement of performance is a current topic in the management of people in companies, used as a parameter of effectiveness of processes and operations of production. The methods and models of the indicators of current use in the production have concentrated in the assessment of people's performance as determinative resource of the organizational success in the search for the competitiveness. Associated with the classic indicators of performance assessment of the production proceeding, other indicators are used in the assessment of risks and hazards, however with methods focused in the tasks, without connection with the real work activity. The present article explores literature on the models of performance measurement in use in companies and a field research to understand how companies interpret and use indicators that relate health and work, to direct future studies on the subject. Regarding the literature review, one can see that health indicators can be basically divided into two major groups: the legal and managerial indicators. When conducting case studies, it can be realized that companies do not have precisely the concept of health indicator, or were unable to define which of the indicators could be considered indicators of health, considering that absenteeism was the indicator mentioned by the four companies.
\end{abstract}

Keywords: ergonomics; ambulatory complaints; absenteeism; frequency accidents

\section{Introduction}

Performance measurement is a current topic in the field of Production Engineering and design of industrial work. Some evidence is the growing number of researchers and practitioners involved with the subject, the number of articles and books, and the amount of websites on the subject [10].

The evolution of performance measurement can be divided into two phases. The first began in 1880 and lasted until the early 1980s, characterized by an emphasis on measures of financial performance and productivity. The second phase, which began in the late 1980 and continues until nowadays, highlights the need for balanced performance measures (financial and non-financial, in addition to productivity) and integrated to support the new operating conditions inside and outside most companies [7].

The second phase, in turn, can be further broken down into two stages. The first is the "measurement myopia" when it was recognized that companies were measuring the variables incorrectly. The second is the "madness of measurement," when companies are obsessed with measuring and want to measure everything according to Neely and Austin (1999) apud Martins et al. (2004). It is worth noting that there are still many companies in the first phase, i.e., companies that are still measuring performance incorrectly [11].

The need for companies to survive in an increasingly competitive market leads them to seek a greater understanding of the relationship of cause and effect of their actions on profitability, requiring information to guide them on their competitive performance. The accounting and financial information are critical, but only record that these events occurred. The measures of performance of time, quality, waste and productivity, complement the financial one, generating improvements in the operational processes [20].

Companies should collect and systematize all the information available so that they signal or allow the execution of their strategy to be successful in their business and remain in business. Some simple information such as waste of raw materials, level of capacity utilization, employees' suggestions can be a differentiating factor in the success of your business [20].

Neely (1999) identifies that the need to implement performance measurement is mainly for the following reasons: (1) changes in the nature of work, (2) increased competition, (3) initiative to specific 
improvements, (4) national and international rewards, (5) role of organizational change, (6) external demands for change, and (7) the strength of information technology.

In general, the performance indicators are used to: [14]

- Measure and analyze performance processes aimed to the needs and expectations of customers;

- Facilitate the establishment and deployment of organizational goals;

- Critically analyze the results of the processes and enable decision making;

- Check the efficiency and effectiveness of organizational processes.

Therefore, the indicator is defined as a quantitative value achieved over time (a statistical function) that provides information about characteristics, attributes and results of a product or service, system or process.

The main types of performance indicators in the literature are:

1) Strategic indicators: they tell "how much" the organization is achieving its vision. They reflect the performance against the critical factors for success.

2) Indicators of Productivity (efficiency): they measure the proportion of resources consumed in relation to the output processes.

3) Quality Indicators (effectiveness): they focus on measures of customer's satisfaction and the characteristics of product/service.

4) Indicators of Effectiveness (impact): they focus on the consequences of products/ services. Doing the right thing the right way.

5) Capacity indicators: they measure the responsiveness of a process through the relationship between the output produced per time unit [3].

However, these classic indicators evaluate the performance of production processes, without reference to actual work, i.e., without considering risks, dangers and constraints of operators carrying out their work activities. Even when indicators are used for evaluation of working conditions, they focus on the tasks prescribed.

From this, the present study seeks to find indicators in the literature related to working conditions, which consider the impact of risks on the operators, and look at how companies use these indicators in practice.

\section{Materials and methods}

This study has been developed through a partnership with Fundação de Amparo a Pesquisa do Estado de São Paulo (FAPESP). The aim of this paper is to identify and formulate indicators for businesses' use, highlighting the indicators of the work and health relationship. Regarding performance indicators, there are many models of performance measurement systems, however, in relation to health indicators; there are no models/formal systems of measurement.

Accordingly, two specific goals are established:

- Identify in the literature indicators related to working conditions;

- How companies use health indicators in practice.

This article first involved a review of the issue of productivity indicators of the health-work relationship and, later, the methodology used was study of multiple cases, which consisted of four interviews with HR managers of large companies. The interviews lasted around 30 minutes, with open interviews and a basic guide without closed questions.

The purpose of the field research was to understand how companies interpret and use indicators that relate health and work, to direct future studies on the subject.

The survey instrument consists of a script, with the following questions, made to guide the interviews:

1- What quantitative indicators does the company use to measure performance in health/safety?

2- What qualitative indicators does the company use to measure performance in health/safety?

3-Among these indicators, which one (s) are those that generate more meaningful data?

4-How are the data obtained by these indicators managed?

5- What people/area/section is/are responsible for collecting these indicators?

6- Have you worked with any indicator that was not efficient, and because of that, no longer use it?

7-Do you try to use "legal" (related to regulatory standards) indicators, or did you "create" any indicator according to a certain inner need?

8-How did the choice of indicators used in this company happen?

9-Is there any difficulty of use/application of the indicators used?

10-Is there any suggestion for a better use/application of the indicators? 


\section{Researched indicators}

Regarding the literature review, indicators that can be used for performance measurement of work activity and indicate relationship to the activities of operators were found.

\subsection{Intensification of work}

According to Dal Rosso (2008), any work autonomous or heteronymous, salaried or cooperative, slave or servant, peasant, worker or intellectual - is held according to a certain intensity degree. It is a condition inherent in all concrete work and is present in all types of work done to a greater or lesser degree.

Intensity has to do with the way the act of working is done. This is the first thing to highlight about intensity: it refers to the degree of energy expenditure performed by workers in the concrete activity [5].

\subsection{Work pace}

Regarding the work organization, it was found that the pressure for productivity increase has a direct influence on the loss of quality of care, which highlights the importance of this indicator in the intensification of work [17].

The work pace requires more attention and supervision because there is a greater number of operations to perform and/or because the fired fellows' work was divided among those who remained with the company. The accelerated pace of work is a constant, noticed by men and women alike, and this appears to be an "effect" of the implementation of Japanese techniques detected not only in Brazil. The responsibility - transferred to the employee - of keeping the pace of production upstream and downstream, is a situation that often encourages the adoption of uncomfortable, not appropriate physical postures. With the intensified pace of work there has been a lot of health problems, from fatigue to tendonitis and even increase in cases of RSI (repetitive strain injuries) [9].

Therefore, at the same time that new technologies increase the worker's safety, they relieve certain physical effort and facilitate the tasks, and also bring new time charges, accelerate the work, increasing mental and physical pressures [9].

\subsection{Ambulatory complaints/pain complaint at work}

The use of different technological resources with diverse forms of control and organization is contributing to workers' exposure to different types and intensities of risk, mediated by the particularities of various industrial processes [16].

Health complaints are little understood by the companies' medical services, because they often relate to the effects of the technology race and the lack of time to meet the goals and deadlines [1].

In the study by Queiroz and Maciel (2001), they mention several authors who argue that ergonomics has shown that repetitive movements, use of force, incorrect postures at work, factors related to the organization's activity and the environment frequently occur in all industrial activity and can cause health problems to the worker, increase the absenteeism and affect their activities of daily living.

The presence of discomfort and pain in the workplace is very common and can be found in several studies like the study by Santos (1994) about ergonomic projects in call centers, in which by evaluating symptoms and complaints of users in daily work, it was found that in six call centers studied (passive centers with workdays of 6 hours without pauses with an interval of 20 minutes for a snack), between $36.8 \%$ and $66.6 \%$ of the evaluated attendants complained about feeling frequent headaches and between $10 \%$ and $25 \%$ made reference to daily headaches, and used daily medication. In addition to the headaches, there were complaints of frequent pain on the back between $51.60 \%$ and $66.90 \%$ of the attendants (lumbar and cervical), on legs between $13 \%$ and $46.50 \%$ of the attendants, eyestrain between $25 \%$ and $59.10 \%$ of the attendants, pain and other symptoms in the hands between $8.30 \%$ and $31 \%$ of attendants [17].

\subsection{Difficulties in performing tasks}

In many studies it is found the report of difficulties perceived by operators in performing their tasks, for example, the study on call centers, where the physical work environment interferes with the workload: - the lack of acoustic treatment, combined with large concentration of people in the room, becomes a disturbing element in performing the activity. The noise level interferes with understanding the client's request and therefore the quality of care [17].

Another factor that may hinder the performance of tasks is inappropriate furniture, as in the study by Santos (1994) in which the tables are not adjustable and are inadequate to the use of computerized systems. The chairs are adjustable, but not al- 
ways all these adjustments are used for lack of the user's awareness. It was even used as an analytical tool the form of Difficulty Analysis Activities - DAA. This was created to receive the information or data of operations reported by the operators.

The study by Duarte and Mauro (2010) also showed the operators' difficulty performing their activities; and regarding the ergonomic risk factors stood out: inadequate distribution of staff and/or team $(83.3 \%)$; insufficient knowledge of the principles of ergonomics $(73.3 \%)$; wards with inadequate architectural environment (layout) of the job posts $(73 \%)$, inadequate load handling (63.3\%); lack of tools and/or instruments for performing the tasks $(60 \%)$; need to adopt awkward postures of the body (53.3\%); inadequate space to perform the activities (50\%); insufficient furniture in the wards and inadequate storage of materials $(30 \%)$; adoption of body postures for prolonged periods $(23.3 \%)$.

Regarding other difficulties, it is highlighted that the workplaces of the team studied evidenced in the research are inadequate to the work of professionals, as in their physical environment, space, ventilation and temperature are not in accordance with the regulations proposed [6].

\subsection{Absenteeism}

In order to improve and increase productivity, companies need to manage and monitor the number of absences from work of their employees, which is another important indicator of health for them. Used to designate the deliberate absence of workers in the work process, the term "absenteeism" can find a wide range of issues that directly affect the employees' quality of life [12].

Among the so-called human factors in the work process, including the so-called occupational diseases and turnover, absenteeism is one of the most damaging effects to the work process, the worker's social support. Absenteeism is characterized in that sense as having a dual effect: from the worker's point of view, the possibility of deductions in salary, layoff or other related problems; in terms of work organization, the difficulty of achieving the planned work and the damages arising by chance [15].

The formula for calculating the absenteeism, according to [9], is:

Absenteeism rate $=\frac{\text { Number of men/days missed through absence from work }}{\text { Average number of employees } x \text { number of working days }} \times 100$
It can be classified as: absenteeism-illness (justified absences for sick leave); absenteeism due to occupational disease (work accident and/or occupational disease); legal absenteeism (protected by law, such as pregnancy, disgust, gala, blood donation and military service); compulsory absenteeism (suspension imposed by the employer, by arrest or other prevented from attending work), and voluntary absenteeism (unexcused personal reasons). The employee may even be absent from work for reasons of family character, for reasons of force majeure, financial difficulties or problems, transport problems, low motivation to work, poor leadership oversight and inadequate policies of organization. Absenteeism in relation to the organization of work has been translated into dissatisfaction, lack of motivation and work team overload [18].

Toldrá et al. (2010) stated that the increased illness and disability among workers is due to a combination of factors, such as workload, unhealthy and dangerous work processes, use of obsolete equipment and technology, harsh working environments, problems of the organization of work and new forms of labor division.

Absenteeism has demanded a lot from organizations and their managers, because their causes are linked to several factors, ranging from social issues, health, personnel management, among other problems, thus making this subject complex and difficult to manage [15].

\subsection{Frequency Rate and Severity of Accidents}

The International Labor Organization uses three indicators to measure and compare the hazard among different sectors of economic activity in a country: the frequency rate, the severity rate and the incidence rate [19].

NB 18 (ABNT, 1975), suggests the construction of the following indicators: (i) frequency rates (total, with time loss and without time loss), (ii) severity rate and severity assessment measures (average number of days lost as a result of total temporary disability, average number of days lost as a result of permanent disability and average computed) [19].

The indicators of accidents at work, besides providing evidence for the determination of levels of dangerousness by professional area, are of great importance for the evaluation of occupational diseases, and absolutely indispensable for the correct determination of programs of prevention of accidents and consequent improvement of working conditions in Brazil [19]. 
The Frequency Rate (Rf) measures the number of accidents occurred for every one million man-hours worked. [19].

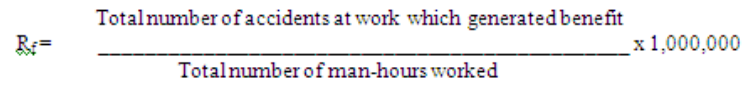

Where:

$\mathrm{Rf}=$ Frequency Rate

$\mathrm{M}=$ Men exposed to hazard

$\mathrm{W}=$ Workday

$\mathrm{T}=$ Time studied in days

Similarly, also expressed as a linear coefficient, the value of TG relates the number of working days missed from accidents with leave to the number of hours worked during the reference period:

Number of days missed from accidents with leave $\mathrm{x} 1,000$ $\mathrm{TG} \mathrm{Calc}=$

Number of hours worked

\subsection{Epidemiologic and Technical Security System} Nexus-ETSSN

The ETSSN, from cross-checking the code of the International Statistical Classification of Diseases and Related Health Problems - ICD and the code of "Classificação Nacional de Atividade Econômica - CNAE" (National Classification of Economic Activity) indicates the existence of a relationship between the injury or grievance and the activity performed by the worker. The indication of ETSSN is rooted in scientific studies in line with the fundamentals of statistics and epidemiology. From this reference the medical expert of INSS gets one more important tool to assist in their analysis for the conclusion about the nature of the incapacity for work shown either of security or incidental nature [2].

The ETSSN was implemented in the computer systems of the INSS, for granting benefits in April/2007 and immediately caused a radical change in the profile of granting disease benefit of incidental nature: there was an increase of about $148 \%$. This value allows us to consider the hypothesis that there was a masking notification of occupational accidents and illnesses [2].

By implementing the ETSSN, the medical expert starts adopting three sequential and hierarchical steps for the identification and characterization of the disability nature - whether accidental or nonaccidental (social security) [4].
The three steps are:

- Identification of the occurrence of Professional or Labor Technical Nexus - PTN/L - verification of the relationship "injury - exposure" or "exposure - injury" (Lists A and B of Annex II of Decree No. 6.042/2007);

- Identification of the occurrence of Epidemiologic and Technical Security System Nexus ETSSN - finding the intersection of CNAE code with the code of ICD-10 and the presence in the matrix of the ETSSN (published in List B of Annex II of Decree No. 6.042/2007);

- Identification of the occurrence of Disease Technical Nexus Likened to Occupational Accident DTNLOA - involves individual analysis of the case by the intersection of all elements brought to the attention of the medical expert of the situation generating the disability and anamnesis [4].

\section{Results}

Regarding the interviews, one can see that each company has its own internal health programs, however, they follow a basic model, such as the PMCOH (Program of Medical Control of Occupational Health) and PRAP (Program of Risk and Accident Prevention), which consist of regulatory standards of the Ministry of Labor and Employment.

The health indicator common to all companies is absenteeism. Other indicators are not used and often they are not even known.

\subsection{Company 1}

The health program of this company has two "strands": Assistance Program and Occupational Medicine.

- Assistance Program: is a program of employee benefits. It consists of a program of guidance and follow-up of employees' health in terms of doctor visits, exams, surgeries, etc.

- Occupational Medicine Program: in this program, security engineering through programs like the PRAP, collects the risk data. These risks involve the ergonomic, chemical, respiratory, thermal, accidents, etc.

After collecting these data, they perform the measurement of these risks and send them to the occupational physician. This, based on the nature of these risks, asks for additional exams, such as blood exams, audiometry, ECGs.

The exams made by the physician are hiring, periodical, change of position and firing ones. 
One year after the examination by the employee, the doctor will see what "factors" of the exams were normal and abnormal. As for those who were abnormal, they will seek solutions. There are more immediate solutions like the use of IPEs, but there are also cases which require deeper solutions like carrying out projects.

For each risk, there is a program of "combat" to it, for example: risks to hearing, there is the HCP (Hearing Conservation Program), for chemical hazards, there is the RPP (Respiratory Protection Program).

For the indicator "complaints," the complaint comes to the occupational therapist of the company, who holds the anamnesis and sends the case to the doctor, who asks for additional exams to be able to point the causal nexus. At this point, the complaint is registered. They use the indicator: number of complaints by area.

Each program has its goals, providing the Performance Plan for each employee.

The indicator absenteeism is also used. It can be classified as non-medical or medical. The medical is when the absence was justified, and nonmedical when it was not justified.

The manager said that a company that invests in health may cost more in the short term than one that does not invest, but it will certainly benefit only in the long term. According to him, there is no way to speak of indicators, without mentioning risk mapping before. These risks are not only health, but also reputation, legislation (enforcement agencies) as well as ethical/moral (concerns about operators' health. Slogan "Our concern is about health and safety," to what extent this is true). He finally emphasized: well monitored indicators $=>$ competitive advantage.

\subsection{Company 2}

The model used by the company to address its health indicators is based on the model MCOHP (Medical Control and Occupational Health Program). Exams are performed: hiring, periodical, firing, audiometric, visual acuity, returning to work and when there is a change of job. These exams are performed by legal periodicity and their results are based on monitoring employees' health, mainly of the MOD. This monitoring is done periodically so that if something different appears on the exams there is time to take measures.

It also made an annual report of each case. When you need to take action, changes are made like changes of IPEs used, change of job post. In more serious cases, it is also made "counter-evidence," which would be a more specific analysis of the event, held outside the company.

The follow-ups can be individual or collective. The individual measures are individual protection equipment (IPE) and the collective are the environmental (environmental reports), which are conducted by third parties, and they assess the physical risk factors such as noise, accidents, and temperature. For each risk there are actions, for example, for noise, there are confines of machines; there is thermal insulation for heat, exhaust, etc.

The indicator ETSSN is used by the company, evaluated together with the safety engineering and medical area.

Other indicators:

- Monthly absenteeism rate;

- Reasons for absenteeism;

- Leave for health problems;

- Exams performed during working hours: they are asking employees to schedule exams outside working hours as an attempt to reduce this indicator.

The company is divided in business units. These units are autonomous, but interdependent. Each unit has its "owner".

\subsection{Company 3}

The company has 2 teams related to health, one internal and another external.

In the internal team, the employee goes to the doctor with his/her complaint. The company's doctor will indicate the treatment or forward to another doctor outside the company, and if so, the company is responsible for monitoring this case. The health program follows the company's health PMCOH models, SESMT ${ }^{1}$, and there is an ergonomics program that is responsible for breaks/labor gymnastics, occupational rehabilitation and reintegration, monitoring of projects (all new projects are followed by the new ergonomics team).

When the company doctor identifies the causal nexus of the employee's complaint about the work, the company ergonomics team studies the case and performs analysis of the posts and the need for adjustments to the workplace.

The external team is responsible for exams that are not made in the company and the focus is on

\footnotetext{
${ }^{1}$ Service Especialized in Safety Engineering and Labor Medicine
} 
occupational health. All exams are made based on the relationship with work.

The company also has an agreement with "Unimed" 2 on medicinal products and tracking of cases.

The only health indicator the company uses is absenteeism, which is linked to the data from the ward (the operator's complaint).

\subsection{Company 4}

Each manager has a plan of action, i.e., a plan to achieve goals.

One of these plans is named P3E (Program of Enterprise Excellence Embraer), which is divided in 3 "dimensions": values, proceedings and people. Within "people" are all activities involving the HR, such as managing people, careers, and health and quality of life at work. pany, there is:

Regarding the indicators used by the com-

- Absenteeism;

- Overtime: the relationship between the number of accidents and absenteeism;

- An indicator of reintegration will be implemented;

- Safety indicators like frequency and severity of accidents: there is a new security program, "Behavior Program," in which was set up a committee (the president of "CIPA" 3 , a security technician, the HR manager, the supervisor of occupational safety and ergonomics and the operator's manager and supervisor) that will go to where there was an accident or incident to investigate how the accident/incident happened;

- Pure health indicator: not yet implemented, but the goal is a census of people's life habits, influencing their health.

Regarding the HR supervisor, there are other controlled indicators, such as:

- Number of people who smoke;

- Number of people who drink booze;

- Number of people who are addicted to drugs;

- Number of people with high cholesterol;

- Number of people with diabetes

- Number of people who are overweight, among others.

The health model starts when the operator comes to the clinic and puts his/her complaint in a totem. Then the doctor looks at him/her, and, if ap-

\footnotetext{
${ }^{2}$ A health insurance company in Brazil

3 "CIPA" = Internal Commission for Accident Prevention
}

propriate, forwards him/her to an expert who will solve the problem or withdraw the operator, who after returning from leave, is evaluated by the group of ergonomics to be reinserted. If there is no need to refer to the specialist, the very company's physician decides whether there is need for leave or opening of "CAT" , and when the person returns to work, is also evaluated by the ergonomics.

There is also a partnership with Unimed, which works as a health insurance to help the operators schedule external medical appointments.

\section{Discussion and conclusion}

Regarding the literature review, one can see that health indicators can be basically divided into two major groups: the legal and managerial indicators.

The legal indicators consist of indicators based on regulatory standards, and are used as instruments of surveillance and even punishment by organs of inspectors, which makes them regulators of workers' operating methods.

On the other hand, the indicators referred as managerial are the indicators "created" by the organization itself, seen as auxiliary tools for measuring performance and occupational health conditions.

By analyzing what the literature brings on these indicators, it is possible to conclude that there is a wide range of health indicators; however, it is interesting that they are restricted in some useful indicators for companies and organizations.

When conducting case studies, it can be realized that companies do not have precisely the concept of health indicator, or were unable to define which of the indicators could be considered indicators of health and, in general, their programs are based on regulator standards like PMCOH, PRAP, SESMT, among others.

Considering that absenteeism was the indicator mentioned by the four companies, it can be considered a very useful performance indicator of manpower because it provides information on system productivity and manpower, since the absenteeism may result from dividing the total number of hours projected by the total number of hours worked. This indicator can be defined as an rate of leave for medical reasons (RMR). By studying the reasons for why

\footnotetext{
4 "CAT" = Communication of Work Accident
} 
the absences occur, a link to the ICD (International Classification of Diseases) lets you check whether the disease is related to work activity, i.e., it allows to verify the causal nexus.

Therefore, when considering the literature very wide and companies do not have proper knowledge about health indicators, the need and relevance of indicators are justified to better define the indicators for organizations and also provide models that can measure their performance in occupational health more clearly.

In conclusion, research and interventions in ergonomics use assessment tools of working conditions built from the interaction between the analyst and the observed which work as a performance measure of the relationship man/work regarding ergonomic hazards analyzed. The use of a results measurement system and validation of proposals for improvement of work situations used in ergonomics can also be understood as a measure of performance evaluation, either of quality of interventions, or the perception of improving conditions of work by operators.

\section{References}

[1] Assunção, A.A. Uma contribuição ao debate sobre as relações saúde e trabalho. Ciência \& Saúde Coletiva, v.8, n.4, p. 1005-1018, 2003.

[2] BRASIL, INSTITUTO NACIONAL DO SEGURO SOCIAL. Brasília, 2011. Disponível em: http://www.previdencia.gov.br/conteudoDinamico.php?id=4 63. Acesso em 29-05-2011, 12:53h.

[3] BRASIL, MINISTERIO DA DEFESA, Brasilia, 2011. Disponível em: http://www.consulting.com.br/edsonalmeidajunior/admin/do wnloads/indicadoresdedesempenho.pdf $>$. Acesso em 25-082011, 01:01h

[4] BRASIL, MINISTÉRIO DA PREVIDÊNCIA E ASSISTÊNCIA SOCIAL. Brasília, 2011. Disponível em: http://www.mpas.gov.br/conteudoDinamico.php?id=559. Acesso: 30-05-2011, 15:38h.

[5] Dal Rosso, S. Mais trabalho!: a intensificação do labor na sociedade contemporânea. São Paulo: Boitempo Editorial, 2008.

[6] Duarte, N.L.; Mauro, M.Y.C. Análise dos fatores de riscos ocupacionais do trabalho de enfermagem sob a ótica dos enfermeiros. Rev. Bras. Saúde Ocup., São Paulo, v.35, n.121, p.157-167, 2010 .

[7] Ghalayini, A. M.; Noble, J. S. The changing basis of performance measurement. International Journal of Operations \& Production Management, v. 16, n. 8, p. 63-80, 1996.

[8] Lewinski, S.M. et al. A utilização do prêmio de produção como ferramenta para redução de custos industriais: Estudo de caso em uma indústria de beneficiamento de madeira.
Congresso Internacional de Administração. Ponta GrossaPR, 21 a 25 de Setembro de 2009.

[9] Lombardi, M.R. Reestruturação produtiva e condições de trabalho: Percepções dos trabalhadores. Educação \& Sociedade, ano XVIII, no 61, dezembro/97.

[10] Martins, R.A. Uso da Informação sobre desempenho como direcionador de projeto de sistemas de medição de desempenho. XXII Encontro Nacional de Engenharia de Produção (ENEGEP) Curitiba - PR, 23 a 25 de outubro de 2002.

[11]Martins, R.A.; Mergulhão, R.C.; Canevarollo, M.E.A.P. Uma investigação empírica sobre a dinâmica da medição de desempenho. XI SIMPEP - Bauru, SP, Brasil, 08 a 10 de novembro de 2004.

[12] Miara, C.; Ahres, R.B.; Ahres, S.B. A Ginástica Laboral como instrumento de alívio de tensões e desconforto muscular do estivador no Centro Logístico: estratégias para uma qualidade de vida no trabalho. Disponível em: < http://www.cescage.edu.br/site/pagina/arquivos/revista/innova re/artigos/8ceaA_Ginastica_Laboral_como_instrumento_de_a livo_de_tensoes_e_desconforto_muscular_do_estivador_no_C etro_Logistico_estrategias_para_uma_qualidade_de_vida_no_ trabalho..pdf $>$. Acesso em: 12 de Julho de 2010.

[13] Neely, Andy. The performance measurement revolution: Why now and what next? International Journal of Operations \& Production Management. MCB University Press. v. 19, n. 02, p.205-228, 1999 .

[15] Oliveira, E.L. et al. Indicadores de Desempenho: um estudo de caso em uma empresa alimentícia. Disponível em: $<$ http://revista.unilins.edu.br/index.php/cognitio/article/viewFil e/172/178> Acesso em: 25-08-2011, 12:52h.

[16]Penatti, I.; Zago, J. S.; Quelhas, O. Absenteísmo: As conseqüências na gestão de pessoas. In: III SEGeT SIMPOSIO DE EXCELENCIA EM GESTÃO E TECNOLOGIA. Associação Educacional Dom Bosco (AEDB), 2006. p.1-11.

[17]Queiroz, M. F.; Maciel, R.H. Condições de trabalho e automação: o caso do soprador da indústria vidreira. Rev Saúde Pública, São Paulo, v.35, n.1, p.1-9, 2001.

[18]Santos, V., et al. Projeto ergonômico de centrais de atendimento. Rio de Janeiro: Ergon Projetos, 1994.

[19] Silva, D. M. P. P.; MARZIALE, M. H. P. Problemas de saúde responsáveis pelo absenteísmo de trabalhadores de enfermagem de um hospital universitário. Acta Scientiarum. Health Sciences. Maringá, v. 25, no. 2, p. 191-197, 2003.

[20] Silva, G.M. Implementação de Mudança: Uma aplicação de um sistema de medição de desempenho - SMD. 138 páginas Mestrado de Engenharia de Produção da Escola de Engenharia da Universidade Federal de Minas Gerais. Belo Horizonte, 2003.

[21] Silva, M. Q. Proposta de redução da taxa de frequência de acidentes em um componente automobilístico. 2003. $52 \mathrm{f}$. Monografia (Especialização, Gerencia de Produção MBA) Departamento de Economia, Contabilidade, Administração e Secretariado - ECASE, Universidade de Taubaté, Taubaté

[22] Toldra, R.T. et al. Facilitadores e barreiras para o retorno ao trabalho: a experiência de trabalhadores atendidos em um Centro de Referência em Saúde do Trabalhador - SP, Brasil. Rev. Bras. Saúde Ocup., São Paulo, v.35, n.121, p.10-22, 2010 . 